\title{
THERMAL COMPRESSION EFFECT ON SEVERAL PROPERTIES OF 8-YEAR-OLD WARU GUNUNG (HIBISCUS MACROPHYLLLUS) WOOD
}

\author{
Basri $\mathbf{E}^{1, *}$, Yuniarti $\mathbf{K}^{1} \&$ Saefudin $^{2}$ \\ ${ }^{1}$ The Center for REDD on Forest Products, Bogor, Indonesia \\ ${ }^{2}$ Biology Research Centre, Indonesian Institute of Science, Bogor, Indonesia \\ *denvig@yahoo.com \\ Submitted January 2021; accepted August 2021
}

\begin{abstract}
The study aimed to investigate the effect of thermal compression on the properties of 8-year-old waru gunung wood. Wood specimens with the dimension of $25 \mathrm{~mm} \times 100 \mathrm{~mm} \times 150 \mathrm{~mm}$ in thickness, width and length, respectively were heated at $180{ }^{\circ} \mathrm{C}$ and $200{ }^{\circ} \mathrm{C}$ for $4 \mathrm{~h}$. During the heating process, the specimens were subsequently compressed at $2.452 \mathrm{~N} \mathrm{~mm}^{-2}$ for 40 mins at each temperature. Changes in the wood chemical structure were examined using the pyrolysis-gas chromatography-mass spectrometry, the wood physical properties were tested according to ASTM D143-94, the wood surface hardness was tested using a Universal Testing Machine and the wood discoloration was examined using the CIELab method. The changes in crystallinity degree was examined using x-ray diffraction and cell structure were collected as supporting data. Results showed that the thermal compression at $180{ }^{\circ} \mathrm{C}$ and $200{ }^{\circ} \mathrm{C}$ caused severe degradation on the specimen carbohydrate but less for lignin. The sum effect of thermal compression on the specimens also consecutively increased the density by $34.24 \%$ and $41.87 \%$ and surface hardness by $52.78 \%$ and $63.09 \%$ and decreased the swelling thickness by $38.54 \%$ and $47.03 \%$ and the equilibrium moisture content by $36.53 \%$ and $38.59 \%$ at $180{ }^{\circ} \mathrm{C}$ and $200{ }^{\circ} \mathrm{C}$, respectively. Thermally compressed specimens also had darker colours, glossier surfaces and smoother texture compared to non-thermally compressed specimens.
\end{abstract}

Keywords: Eight-year-old wood, thermal compression, properties

\section{INTRODUGTION}

Waru gunung (Hibiscus macrophyllus) is one of the fast-growing tree species widely planted in Java island, Indonesia. The trunk of the 9-yearold tree can reached a height of $28 \mathrm{~m}$ and a diameter at breast height of $25-30 \mathrm{~cm}$ (Susanto \& Mashudi 2017). The wood appearance is slightly brown in colour, slick and shiny and has a straight fibre direction. Due to these characteristics, waru gunung wood has been used as raw materials for furniture by small to medium enterprises in Java island.

Presently, the use of young waru gunung is still limited to extremely light furniture. The wood needs to be modified in order to expand its usage spectrum as heavy furniture and/or construction material. Densification technology is an effective method to improve the quality of inferior wood. The technology not only improves the wood strength properties but also enhances its surface quality. Therefore, the densified wood can be further converted into products with high commercial value such as flooring and furniture (Belt et al. 2013, Song et al. 2018).

The densification of wood can be performed physically with or without heating process. Thermal compression which combines the use of high-temperature heating and mechanical pressing to produce densified wood is currently gaining attention (Candan et al. 2013, Rautkari et al. 2013, Choowang \& Hiziroglu 2015, Dogu et al. 2016). A single heat treatment above $150{ }^{\circ} \mathrm{C}$ will affect the wood hemicellulose generally present in a range of $18 \%-35 \%$ within the trees (Moliński et al. 2016). The degradation of wood hemicellulose may cause some amorphous regions to change into crystalline regions. These regions are void of effective free $\mathrm{OH}$ groups, thus decreasing the wood moisture content (Esteves et al. 2011). As a result, the equilibrium moisture content of the wood will decrease due to the reduced hygroscopic properties of wood and the dimensional stability of the wood will further 
increase (Pelit et al. 2015, Shukla 2019, Priadi et al. 2019). Furthermore, the hemicellulose degradation (Gasparik et al. 2019) is similar to lignin degradation (Shmulsky \& Jones 2019) as both contribute to the discoloration of wood.

Heating treatment also soften the wood structure and makes it easier to be compressed. Wood structure often changes because of combined action between heat and compression (Harsono 2016, Tu et al. 2014). Depending on tree species, exposure to heat treatment and thermal compression cause morphological changes of wood. The changes include reduced wood cell lumen dimension, collapsed and flattened vessels, cracked fibre cell walls, ruptured bordered pits and minor damage in ray cells (Darwis et al. 2017, Tu et al. 2014, Dogu et al. 2016).

The use of thermal compression on waru gunung wood had not yet been attempted. The study was necessary to provide information on possible efforts to improve the properties of the wood as they had become more popular among local communities for their source of income. The main aim of this study was to investigate the effect of using thermal compression technology on several properties such as chemical degradations, density, thickness swelling, equilibrium moisture content, surface hardness, colour changes, crystallinity degree and cell structure of 8-year-old waru gunung wood.

\section{MATERIALS AND METHODS}

\section{Wood specimen}

Approximately 10 tangential boards of 8-yearold waru gunung wood were prepared. Each board dimension was $25 \mathrm{~mm}$ (radial $(\mathrm{r}) /$ thickness $) \times 100 \mathrm{~mm} \quad$ (tangential $\quad(\mathrm{t}) /$ width) $\times 1000 \mathrm{~mm}$ (longitudinal (l)/length) . The boards were dried at the temperature range of $40{ }^{\circ} \mathrm{C}-65{ }^{\circ} \mathrm{C}$ until the moisture content reached 12\%. Each board was further sawn into specimens with a dimension of $25 \mathrm{~mm}$ (thick) $\times 100 \mathrm{~mm}$ (width) $\times 150 \mathrm{~mm}$ (length). These specimens were divided into groups of control and thermal densification specimens at random.

\section{Thermal compression}

All wood specimens were dried in an oven at $180{ }^{\circ} \mathrm{C}$ for $3 \mathrm{~h}$. The next stage was followed by thermal compression at $180{ }^{\circ} \mathrm{C}$ and 200 ${ }^{\circ} \mathrm{C}$, respectively. A pressure of $2.452 \mathrm{~N} \mathrm{~mm}^{-2}$ for $40 \mathrm{~min}$ was applied on both temperature treatments.

Changes in the chemical structure of the specimens primarily lignin and carbohydrate due to thermal densification were analysed using pyrolysis-gas chromatography massspectrometry. Changes in the physical properties of thermally compressed control specimens were observed after 1 month of storage at room temperature between $23^{\circ} \mathrm{C}$ and $30{ }^{\circ} \mathrm{C}$ and relative humidity between $76 \%$ and $90 \%$. In each treatment, 10 control specimens were examined for density, thickness swelling and equilibrium moisture content according to the ASTM D143 standard (ASTM 2014). The surface hardness of the specimens was tested using a universal testing machine and dropping a half-circle steel ball with a diameter of $11.25 \mathrm{~mm}$ on to the specimen surface.

Colour changes or discoloration of the specimens due to thermal compression were observed quantitatively using the CIELAB method. This method could measure the values for $L$, $a$ and $b$ (Hunter Lab 2012). L indicated lightness with colour values ranging from 0 (black) to 100 (white), a indicated colour values from green to red with $-\mathrm{a}$ from -80 to 0 corresponding to green and $+\mathrm{a}$ from 0 to 80 referring to red and $\mathrm{b}$ denoted colour values from blue to yellow with $-\mathrm{b}$ from -70 to 0 corresponding to blue and $+\mathrm{b}$ from 0 to 70 referring to yellow. In each specimen, five location points were used for the determination of $\mathrm{L}, \mathrm{a}$ and $\mathrm{b}$ values. The colour change $(\Delta \mathrm{E})$ were calculated as a mathematical function of $\Delta \mathrm{L}, \Delta \mathrm{a}$ and $\Delta \mathrm{b}$ based on the formula below. The colour change values were classified into several criteria (Table 1).

$$
\begin{aligned}
\Delta \mathrm{E} & =\mathrm{f}(\Delta \mathrm{L}, \Delta \mathrm{a}, \Delta \mathrm{b}) \\
& =\left([\Delta \mathrm{L}]^{2}+[\Delta \mathrm{a}]^{2}+[\Delta \mathrm{b}]^{2}\right)^{0.5}
\end{aligned}
$$

where $\Delta \mathrm{E}=$ the colour change value; $\Delta \mathrm{L}=$ the difference in $\mathrm{L}$ value between non-densified 
Table 1 Colour change class and criteria

\begin{tabular}{ccl}
\hline Class & Colour change $(\Delta \mathrm{E})$ values & Criteria \\
\hline I & $\Delta \mathrm{E}<0.2$ & Invisible change \\
II & $0.2<\Delta \mathrm{E}<2.0$ & Very small change \\
III & $2.0<\Delta \mathrm{E}<3.0$ & Small changes (colour changes is visible by high-quality filter) \\
IV & $3.0<\Delta \mathrm{E}<6.0$ & Medium (colour changes is visible by high-quality filter) \\
V & $6.0<\Delta \mathrm{E}<12.0$ & Large (distinct colour changes) \\
VI & $\Delta \mathrm{E}>12.0$ & Different colour \\
\hline
\end{tabular}

Source of reference Hunter Lab (2012)

specimen (control) and densified specimen; $\Delta \mathrm{a}=$ the difference in a value between nondensified specimen (control) and densified specimen and $\Delta \mathrm{b}=$ the difference in $\mathrm{b}$ value between non-densified specimen (control) and densified specimen.

The wood crystallinity degree was observed using x-ray diffraction. The visual changes in wood cell structures were examined using a stereo-capable microscope.

\section{RESULTS AND DISGUSSION}

\section{Ghemical component changes}

The changes in lignin and carbohydrate components of the specimen due to thermal compression were shown in Table 2. The pyrolysis-gas chromatography massspectrometry results showed hot pressing severely degraded the carbohydrates in the specimens which consisted of hemicellulose and cellulose. However, the effect of heat on lignin was minimal.

The depolymerisation percentage of lignin compounds (Total $\mathrm{A}+\mathrm{B}$ ) tended to be much lower than that of carbohydrate compounds (Total C). The observation showed lignin was least degraded and had a greater impact on the low-thickness swelling performance of the densified specimens at $180{ }^{\circ} \mathrm{C}$ and $200{ }^{\circ} \mathrm{C}$ than of carbohydrates. Lignin which was inherently thermoplastic in nature became plastic after exposure to heat. Lignin melted and migrated to the specimen surface, filling all cell cavities, voids and spaces between fibres and microfibrils (Sjostrom 2013). After the cooling process, lignin became hardened and turned into strong adhesive between microfibrils and between fibrils (Choowang \& Hiziroghu 2015).

The degraded lignin compound consisted of phenylpropane and benzene/ phenol derivatives were shown in Table 2. The concentration of eugenol, cispropenylsyringol, trans-propenylsyringol, and coniferyl alcohol which were derivatives of phenylpropane had decreased in the thermally compressed specimens at $180{ }^{\circ} \mathrm{C}$. Eugenol and coniferyl alcohol continued to decrease in specimens being thermally compressed at 200 ${ }^{\circ} \mathrm{C}$. The decrease was due to the fragmentation of two phenylpropane monomers into simpler molecular weight compounds such as the benzene derivatives. The concentration of propenylsyringol initially decreased in specimens thermally compressed at $180{ }^{\circ} \mathrm{C}$ but had increased in specimens exposed to thermal compression at $200{ }^{\circ} \mathrm{C}$. The results suspected that lignin polymer in the specimens which was thermally compressed at $200{ }^{\circ} \mathrm{C}$ underwent more intensive depolymerisation to monomer units of cis-propenylsyringol and trans-propenylsyringol.

Table 2 showed as the pressing temperature increased, the concentrations of benzene derivatives guaiacol, syringol and cresol had increased while the vanillin and syringaldehyde concentration decreased. At the temperature of $200^{\circ} \mathrm{C}$, the concentration of syringaldehyde was undetected. The increase of guaiacol, syringol and cresol could be attributed to the more intensive fragmentation of their phenylprophane monomer derivatives. The decrease in the concentration of vanillin and syringaldehyde could be due to their volatilisation or further fragmentation into a 
Table 2 Changes of lignin and carbohydrate polymers in densified and undensified specimens

\begin{tabular}{|c|c|c|c|c|c|c|c|}
\hline \multirow[b]{2}{*}{ No } & \multirow{2}{*}{$\begin{array}{l}\text { Identified fragment compounds from the } \\
\text { degradation of wood constituents }\end{array}$} & \multicolumn{3}{|c|}{ Chemical aspects $^{1}$} & \multicolumn{3}{|c|}{ Concentrations (\%) } \\
\hline & & $\begin{array}{l}\text { Chemical } \\
\text { formula }\end{array}$ & $\begin{array}{c}\mathrm{BP} \\
\left({ }^{\circ} \mathrm{C}\right)\end{array}$ & $\begin{array}{c}\text { MW } \\
\text { (g/mole) }\end{array}$ & \multicolumn{3}{|c|}{ Treatment } \\
\hline \multirow[t]{4}{*}{ A } & Phenylpropane derivatives* & & & & Control & $180\left({ }^{\circ} \mathrm{C}\right)$ & $200\left({ }^{\circ} \mathrm{C}\right)$ \\
\hline & 1 Eugenol & $\mathrm{C}_{10} \mathrm{H}_{12} \mathrm{O}_{2}$ & 254 & 164.20 & 1.36 & 1.12 & 0 \\
\hline & 2 Propenylsyringol (cis \& trans) & $\mathrm{C}_{11} \mathrm{H}_{14} \mathrm{O}_{3}$ & 306 & 194.23 & 3.64 & 1.99 & 3.01 \\
\hline & 3 Coniferyl alcohol & $\mathrm{C}_{10} \mathrm{H}_{12} \mathrm{O}_{3}$ & 163 & 180.08 & 3.72 & 2.47 & 1.92 \\
\hline \multirow[t]{7}{*}{ B } & Benzene/phenol derivatives** & & & & & & \\
\hline & 1 Guaiacol & $\mathrm{C}_{7} \mathrm{H}_{8} \mathrm{O}_{2}$ & 205 & 124.14 & 1.88 & 2.00 & 2.20 \\
\hline & 2 Syringol & $\mathrm{C}_{8} \mathrm{H}_{10} \mathrm{O}_{3}$ & 261 & 154.16 & 3.73 & 3.78 & 3.80 \\
\hline & $3 \mathrm{Cresol}^{2}$ & $\mathrm{C}_{7} \mathrm{H}_{8} \mathrm{O}$ & 202 & 108.13 & 1.58 & 1.60 & 1.70 \\
\hline & 4 Vanillin & $\mathrm{C}_{8} \mathrm{H}_{8} \mathrm{O}_{3}$ & 258 & 152.15 & 0.83 & 0.80 & 0.75 \\
\hline & 5 Syringaldehyde & $\mathrm{C}_{9} \mathrm{H}_{10} \mathrm{O}_{4}$ & 192 & 182.17 & 0.88 & 0.31 & 0 \\
\hline & Total: A + B & & & & 17.62 & 14.07 & 13.38 \\
\hline \multirow[t]{5}{*}{ C } & Degraded wood Carbohydrate & & & & & & \\
\hline & 1 Acetic acid & $\mathrm{CH}_{3} \mathrm{COOH}$ & 117.9 & 60.05 & 8.70 & 10.71 & 8.53 \\
\hline & 2 Glucosan $^{3}$ & $\left(\mathrm{C}_{6} \mathrm{H}_{10} \mathrm{O}_{5}\right)$ & & & 5.42 & 5.29 & 7.56 \\
\hline & 3 Furans/furfurals & & $<150$ & & 1.80 & 7.35 & 6.40 \\
\hline & Total: C & & & & 15.92 & 23.35 & 22.49 \\
\hline \multirow[t]{2}{*}{$\mathrm{D}$} & Carbondioxide ${ }^{5}$ & $\mathrm{CO}_{2}$ & $<<0$ & 44.01 & 17.30 & 13.83 & 23.71 \\
\hline & Total: A+B + C + D & & & & 51.14 & 51.25 & 59.58 \\
\hline $\mathrm{E}$ & Other carbon-containing fragments ${ }^{4,5}$ & & & & 48.86 & 48.75 & 40.42 \\
\hline
\end{tabular}

$\mathrm{MW}=$ molecular weight, $\mathrm{BP}=$ boiling point;

${ }^{1}=$ source of reference (Rumble 2020), ${ }^{2}=$ from phenol-propane-type monomers,

${ }^{3}=$ degree of polymerization $(\mathrm{x})$ less than that $(\mathrm{n})$ of cellulose,${ }^{4}=$ low molecular weight or low-boiling fragments, ${ }^{5}=$ could be partially from the cell wall degraded chemical components and partially from the degraded/volatilised extractives;

$*$ = monomer units from the depolymerized lignin, $* *=$ from the further degradation or fragmentation of phenyl-propane derivatives

much simpler inorganic chemical structure such as $\mathrm{H}_{2} \mathrm{O}$ and $\mathrm{CO}_{2}$. Lignin fragmentation at high temperatures experienced volatilisation or was converted into simpler chemical structures such as $\mathrm{CO}_{2}$ (Rumble 2020). When the temperature was increased from $180{ }^{\circ} \mathrm{C}$ to $200{ }^{\circ} \mathrm{C}$, the concentration of $\mathrm{CO}_{2}$ in the pressed specimens had increased from $13.83 \%$ to $23.71 \%$, respectively.

The depolymerisation of the wood carbohydrate yielded compounds consisted of acetic acid, glucose and furans/furfurals (Table 2). Acetic acid and furans were assumed to be the product of hemicellulose degradation, whereas glucosans were from cellulose depolymerisation (Shmulsky \& Jones 2019). Furans played an important role in creating lignin-furfural bonds between fibres in thermally compressed specimens (Widyorini et al. 2005). Therefore, the polymer also contributed to the dimensional stability of thermally compressed specimens. When the pressing temperature increased from $180{ }^{\circ} \mathrm{C}$ to $200{ }^{\circ} \mathrm{C}$, the concentration of acetic acid and furans in the specimens had decreased. This was assumed to be due to the continued fragmentation of hemicellulose, which eventually converted into a simpler structure such as $\mathrm{CO}_{2}$. Acetic acid, as one of the product of carbohydrate degradation, could also accelerate the fragmentation of carbohydrates to a much simpler structure (Kucerova et al. 2016).

At high temperatures, hemicellulose which was inherently amorphous in nature could fragment significantly. As a result, 
the amorphous region shrunk, whereas the proportion of crystalline cellulose increased (Kucerova et al. 2016). The reduction in the free $\mathrm{OH}$ group at high temperatures brought the fibrils and microfibrils closer and increased the crystallinity proportion of the heated wood (Shmulsky \& Jones 2019, Esteves et al. 2011). Other than hemicellulose, hardened melted lignin also contributed to the increase in surface hardness of the wood (Akgul \& Korkut 2012, Choowang \& Hiziroghu 2015).

Glucose concentration decreased in the specimens when thermally compressed at 180 ${ }^{\circ} \mathrm{C}$ but increased in specimens when thermally compressed at $200{ }^{\circ} \mathrm{C}$. This happened as glucose underwent further fragmentation to a much simpler structure like $\mathrm{H}_{2} \mathrm{O}$ and $\mathrm{CO}_{2}$ at $180{ }^{\circ} \mathrm{C}$. However, at $200{ }^{\circ} \mathrm{C}$ cellulose underwent further intensive depolymerisation, thereby increasing glucose concentration. The glucose concentration in the thermally compressed specimen was lower than that of acetic acid. This indicated that the semi-crystalline structure of glucose was more resistant to degradation by heat than the amorphous hemicellulose structure (Srinivas \& Pandey 2012).

\section{Physical and mechanical properties}

Table 3 showed the densification temperatures at $180{ }^{\circ} \mathrm{C}$ and $200{ }^{\circ} \mathrm{C}$ significantly increased the specimen density at $34.24 \%$ and $41.87 \%$ and surface hardness at $52.78 \%$ and $63.09 \%$ but decreased the thickness swelling at $38.54 \%$ and $47.03 \%$ and equilibrium moisture content at $36.53 \%$ and $38.59 \%$ when compared to the undensified or control specimens. The density increase was caused by the decrease in specimen volume and thickness due to the hot press process. The volume and thickness decrease was attributed to decreasing volume of the wood cell cavities in the specimen structures (Budakci et al. 2016, Darwis et al. 2017).

Figure 1(b)-(c) showed the effect of high temperature and pressing movement of hot metal plates on wood cells which consisted of pores, rays and fibres to become more elastic and thereby narrowing their shapes in the densified specimens. Rays structures in the densified specimens appeared crushed and buckled when compared to those in the control specimens (Figure 1(a)). The wood fibres, especially the ones near to the surface

Table 3 Average values of physical properties in densified and undensified (control) specimens

\begin{tabular}{|c|c|c|c|c|}
\hline Treatment & Density $\left(\mathrm{kg} \mathrm{m}^{-3}\right)$ & Thickness swelling (\%) & Equilibrium moisture content (\%) & Hardness $\left(\mathrm{N} \mathrm{mm}^{-2}\right)$ \\
\hline Control & $406 \pm 45$ & $5.89 \pm 0.28$ & $12.10 \pm 0.43$ & $9.32 \pm 0.83$ \\
\hline Densified $180{ }^{\circ} \mathrm{C}$ & $545 \pm 18$ & $3.62 \pm 0.09$ & $7.68 \pm 0.18$ & $14.24 \pm 2.76$ \\
\hline Densified $200{ }^{\circ} \mathrm{C}$ & $576 \pm 10$ & $3.12 \pm 0.05$ & $7.43 \pm 0.07$ & $15.20 \pm 2.70$ \\
\hline
\end{tabular}

Average of 10 replications

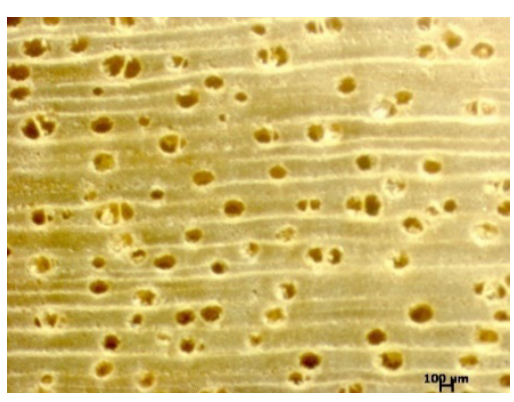

(a)

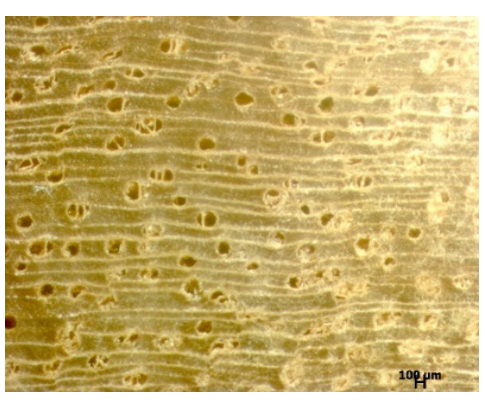

(b)

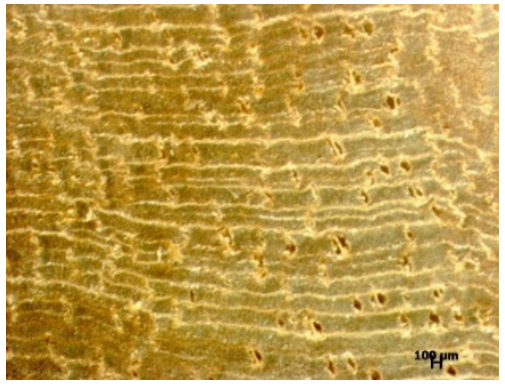

(c)

Figure 1 Cross sectional views of wood cell shape in densified and undensified (control) specimens $\mathrm{a}=$ control, $\mathrm{b}=$ densified at $180{ }^{\circ} \mathrm{C}, \mathrm{c}=$ densified at $200{ }^{\circ} \mathrm{C}$ 
became closer to each other, denser and compacted, thereby increasing the hardness of the densified specimens as compared to control specimens (Table 3) (Budakci et al. 2016, Fang et al. 2019, Augustina et al. 2020). Increased hardness in wood was essential as they were beneficial for flooring (Chowang \& Hiziroghu 2015).

The reduction of equilibrium moisture content in the thermally compressed specimens (Table 3 ) could be attributed to the reduced free $\mathrm{OH}$ group in the specimen cells which resulted from the water condensation during the desorption process. As a result, the hygroscopicity of thermally compressed specimens decreased and the situation was known as the hysteresis phenomenon (Frederikson \& Thybring 2019). The decrease in thickness swelling of the densified specimens (Table 3) could be due to the role of the most heat-stable wood component such as lignin. The observation was because under further hot press densification at $180{ }^{\circ} \mathrm{C}$ and $200{ }^{\circ} \mathrm{C}$, hemicellulose and cellulose would be degraded or depolymerised first, whereas lignin might still be able to withstand heat or remained intact. The heat-treated densification caused the evaporation of free water, bound water molecules as well as low-boiling temperature extractives. The water evaporation could draw the fibrils and microfibrils closer together, thus increasing specimen crystallinity. Figure 2 showed the hot-pressed specimens had an increased degree of crystallinity compared to the control specimens. Higher press temperature could cause higher degree of crystallinity in specimen. Furthermore, the densified specimens thickness swelling at the hot-pressing temperature of $200{ }^{\circ} \mathrm{C}$ was smaller than at $180^{\circ} \mathrm{C}$. The results implied that the recovery-prevention effort at the $200{ }^{\circ} \mathrm{C}$ densified specimens was greater than the $180^{\circ} \mathrm{C}$ densified specimens. The recovery-prevention was related to the phenomena called spring back, whereby the more intense the recoveryprevention effort, the greater would be the capability of the specimen to prevent spring back action (Kocaefe et al. 2015, Darwis et al. 2017). The decreasing capability of wood in adsorbing or desorbing water vapour from and to the air was an essential factor to maintain the quality of wood products, especially those that would be placed in an air-conditioned room or exported to four-season countries with extreme changes in air humidity.

Table 4 showed the $\Delta \mathrm{E}$ values of the control specimens and the thermally compressed specimens at $180{ }^{\circ} \mathrm{C}$ and $200{ }^{\circ} \mathrm{C}$ were 26.18 and

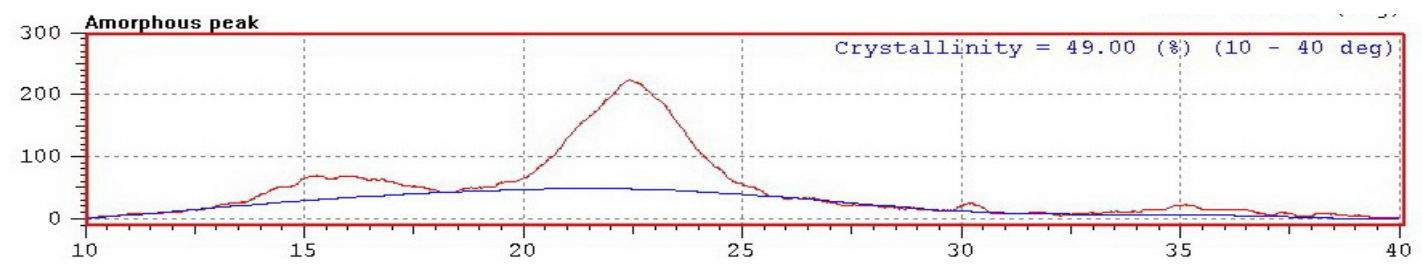

(a)

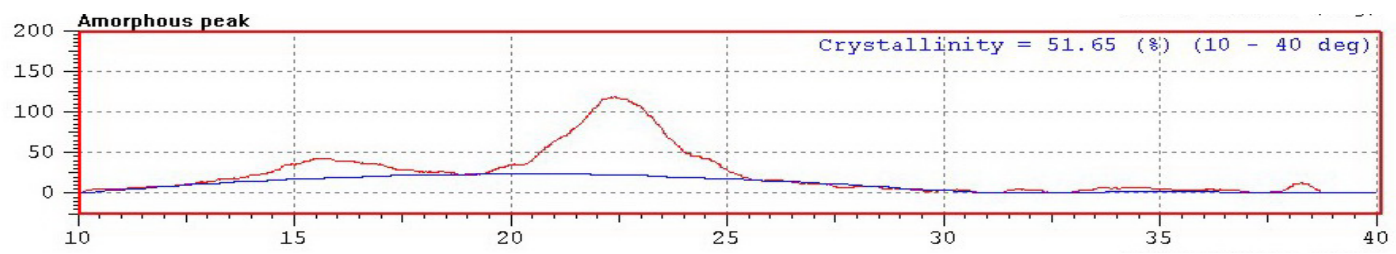

(b)

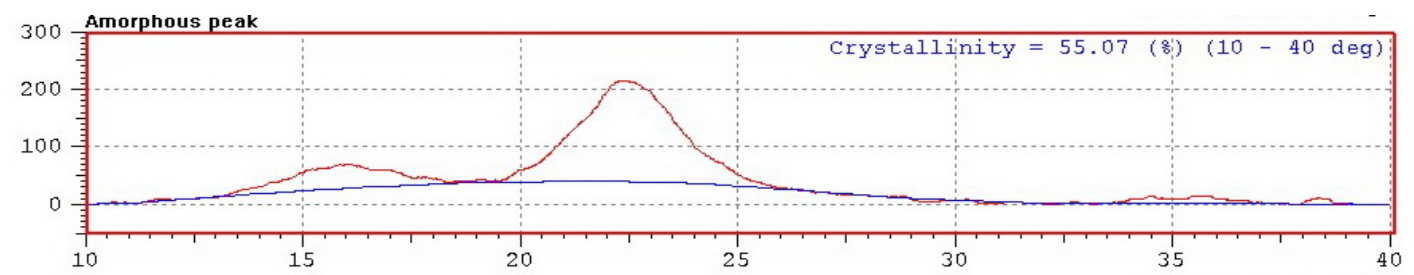

(c)

Figure 2 Crystallinity degree in densified and undensified (control) specimens $\mathrm{a}=$ control, $\mathrm{b}=$ densified at $180{ }^{\circ} \mathrm{C}, \mathrm{c}=$ densified at $200{ }^{\circ} \mathrm{C}$ 
Table 4 Colour and colour change of densified and undensified specimens

\begin{tabular}{|c|c|c|c|c|c|}
\hline \multirow[t]{2}{*}{ Wood specimens } & \multicolumn{3}{|c|}{ Quantitative colour system ${ }^{1}$} & \multirow[t]{2}{*}{ Colour change $(\Delta \mathrm{E})$} & \multirow[t]{2}{*}{ Implication $^{2}$} \\
\hline & $\mathrm{L}$ & $\mathrm{a}$ & $\mathrm{b}$ & & \\
\hline Control/undensified & 79.86 & 4.06 & 20.86 & & \\
\hline Densified (at $180{ }^{\circ} \mathrm{C}$ ) & 56.40 & 11.20 & 30.04 & & \\
\hline Densified (at $200{ }^{\circ} \mathrm{C}$ ) & 46.43 & 13.83 & 30.73 & & \\
\hline NDS vs DS180 & & & & 26.18 & Different colour ${ }^{3}$ \\
\hline NDS vs DS200 & & & & 36.20 & Different colour ${ }^{3}$ \\
\hline DS180 vs DS200 & & & & 10.33 & Distinct colour changes ${ }^{4}$ \\
\hline
\end{tabular}

${ }^{1}=$ averaged from 5 location points, ${ }^{2}=$ reference from Table $1,{ }^{3}=$ colour of the densified specimens at $180{ }^{\circ} \mathrm{C}$ became darker or stronger (blackening and yellowish/reddish red) and intensively stronger at $200{ }^{\circ} \mathrm{C},{ }^{4}=$ wood darkening colour at $200{ }^{\circ} \mathrm{C}$ was more distinct than that at $180{ }^{\circ} \mathrm{C}$ heat press;

NDS = undensified (control) specimens, DS180 = densified specimens at $180{ }^{\circ} \mathrm{C}$, DS200 $=$ densified specimens at $200{ }^{\circ} \mathrm{C}$

36.20 , respectively. The $\Delta \mathrm{E}$ values in both cases were greater than 12.00 , indicating colour differences between the thermally compressed specimens and the control specimens. The $\Delta \mathrm{E}$ value between the specimens thermally compressed at $180{ }^{\circ} \mathrm{C}$ and $200{ }^{\circ} \mathrm{C}$ was 10.33 (Table 4). The results indicated the use of hot pressing at $200{ }^{\circ} \mathrm{C}$ tended to produce a darker colour on the specimen surface than at the temperature of $180^{\circ} \mathrm{C}$. The discoloration of the smoked-wood specimens, where they appeared darker and stronger compared to the non-smoked specimens occurred due to heat exposure during the wood-smoking process (Hadi et al. 2020). Such discoloration of the thermally compressed specimens was due to the presence of the heat-stable or the least degraded lignin. Wood lignin was characteristically light in colour but its chemical structure easily changed and caused the colour to darken (Shmulsky \& Jones 2019). The colour change was also caused by the combustion of the specimen surface in contact with a hot-pressing metal. The combustion was due to the release of hydrogen and oxygen elements from the carbon element, which was naturally black in colour (Kucerova et al. 2016, Gasparik et al. 2019).

Although surface colours of the thermally compressed specimens were darker, their texture was smoother than that of the control specimens (Figure 3(b)-(c)). The surface of the thermally compressed specimens appeared glossy, which was possibly due to the flow of melting, glass-like shiny lignin (Budakci et al. 2015). The lignin flow transition process had rearranged, filled the space and levelled the uneven specimen surface more intensively at a high pressing temperature of $200{ }^{\circ} \mathrm{C}$ (Figure $3(c))$. Therefore, the surface of the thermally compressed specimens would tend to be more attractive and had aesthetic characteristics than that of the non-thermally pressed or control specimens.

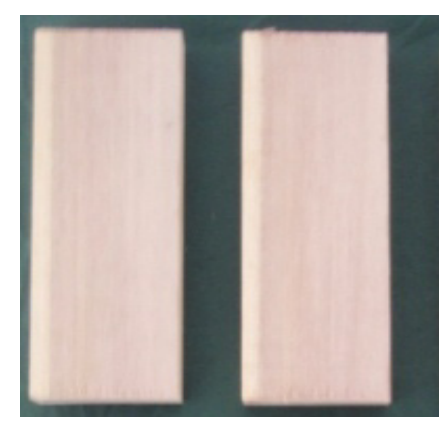

(a)

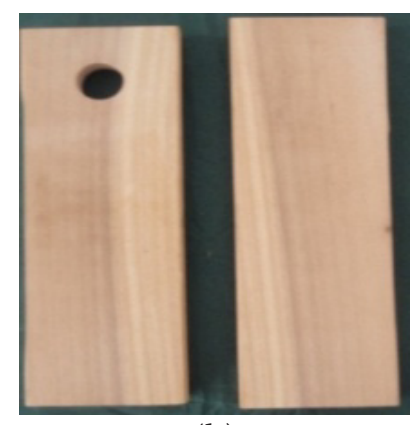

(b)

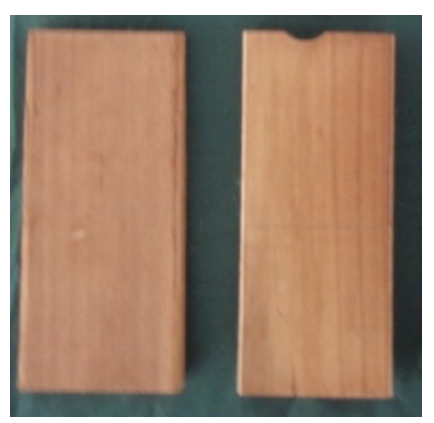

(c)

Figure 3 Visual appearance of densified and undensified (control) specimens $\mathrm{a}=$ control, $\mathrm{b}=$ densified at $180{ }^{\circ} \mathrm{C}, \mathrm{c}=$ densified at $200{ }^{\circ} \mathrm{C}$ 


\section{CONCLUSION}

The thermal compression treatment caused extensive depolymerisation or fragmentation of the chemical components such as hemicellulose, cellulose and lignin of 8-year-old waru gunung specimens. Hemicellulose was the most severely degraded, whereas cellulose experienced less severe degradation and lignin was shown to be the least to degrade. When compared to control specimens, the thermally compressed specimens at the temperature of $180{ }^{\circ} \mathrm{C}-200$ ${ }^{\circ} \mathrm{C}$ and at the pressure of $2.452 \mathrm{~N} \mathrm{~mm}^{-2}$ had increased density and surface hardness but decreased thickness swelling and equilibrium moisture content. The thickness swelling and equilibrium moisture content of the thermally compressed specimens were lower at 200 ${ }^{\circ} \mathrm{C}$ than at $180{ }^{\circ} \mathrm{C}$, whereas their density and surface hardness were higher at $200{ }^{\circ} \mathrm{C}$ than at $180^{\circ} \mathrm{C}$. Nevertheless, the thermally compressed specimens had darker colours, glossier surfaces and more aesthetic appearance at $200{ }^{\circ} \mathrm{C}$ than at $180{ }^{\circ} \mathrm{C}$.

\section{ACKNOWLEDGEMENTS}

The authors gratefully acknowledged the support from The Forest Products R \& D Center, Bogor, which facilitated and funded the majority of the research. High appreciation was dedicated to Prof. Dr. Yusuf Sudo Hadi, who reviewed and gave many valuable inputs for the improvement of this manuscript. All authors provided equal contribution to the manuscript.

\section{REFERENGES}

Astm. 2014. Standard Test Methods for Small Clear Samples of Timber D143 (Revision). Annual Book of ASTM Standards. Volume 4.10 (Woods). 2014 Edition. ASTM International, West Conshohocken.

AкGÜL M \& Korkut S. 2012. The effect of heat treatment on some chemical properties and colour in Scots pine and Uludağ fir wood. International Journal of Physical Sciences 7: 2854-2859. DOI:10.5897/ IJPS12.281

Augustina S, Wahyudi I, Darmawan IW et aL. 2020. Specific gravity and dimensional stability of boron- densified wood on three lesser-used species from Indonesia. Journal of Korean Wood Science and Technology 48: 458-471. https://doi.org/10.5658/ WOOD.2020.48.4.458

Belt T, Rautkari L, Laine Ket AL. 2013. Cupping behaviour of surface densified scots pine wood: the effect of process parameters and correlation with density profile characteristics. Journal of Materials Science 48: 6426-6430. doi:10.1007/s10853-013-7443-1

Budakci M, Pelit H, Sönmez A et al. 2016. The effects of densification and heat post-treatment on hardness and morphological properties of wood materials. BioResources 11: 7822-7838. DOI:10.15376/biores. 11.3.7822-7838

Candan Z, Korkut S \& Unsal O. 2013. Thermally compressed poplar wood (tcw): physical and mechanical properties. Drona Industrija 64: 107111. doi: $10.5552 /$ drind.2013.1216

Choowang R \& Hiziroglu S. 2015. Properties of thermallycompressed oil palm trunks (Elaeis guineensis). Journal of Tropical Forest Science 27: 39-46.

Darwis A, Wahyudi I, Dwiyanto W et al. 2017. Densified wood anatomical structure and the effect of heat treatment on the recovery of set. Journal of Indian Acad Wood Sci 14: 24-31. DOI 10.1007/s13196-0170184-z

Dogu D, Bakir D, Tuncer FD et AL. 2016. Microscopic investigation of defects in thermally compressed poplar wood panels. Maderas. Ciencia y Tecnología 18: 337-348. https://doi.org/http://dx.doi. org/10.4067/S0718-221X2016005000031

Esteves B, Videira R \& Pereira H. 2011. Chemistry and ecotoxicity of heat-treated pine wood extractives. Wood Science and Technology 45: 661-676. https:// doi.org/10.1007/s00226-010-0356-0

Fang CH, Cloutier A, Jiang JH et AL. 2019. Improvement of wood densification process via enhancing steam diffusion, distribution, and evaporation. BioResources 14: 3278-3288. doi: 10.15376/ biores.14.2.3278-3288

Fredriksson M \& ThyBring EE. 2019. On sorption hysteresis in wood: separating hysteresis in cell wall water and capillary water in the full moisture range. PLOS ONE. Doi:https://doi.org/10.1371/journal. pone.0225111

Gasparik M, GafF M, Kacik F et al. 2019. Colour and chemical changes in teak (Tectona grandis L.f.) and meranti (Shorea spp.) wood after thermal treatment. BioResources 14: 2667-2683. doi: 10.15376/ biores.14.2.2667-2683

Hadi YS, Massijaya MY, Abdillah IB et al. 2020. Colour change and resistance to subterranean termite attack of mangium (Acacia mangium) and sengon (Falcataria moluccana) smoked wood. Journal of Korean Wood Science and Technology 48: 1-11. http: // doi.org/10.5658/WOOD.2020.48.1.1

Harsono D. 2016. Treatment efficacy of oil palm lumber (Elaeis guinensis Jacq) using the mixture of borax and boric acid on soil termite attack. Jurnal Riset Industri Hasil Hutan 8: 87-98. 
Hunter Lab. 2012. Application Note: L, a, b Colour Scale. Insight on Colour 1-4. Hunter Associattes Lab., Inc., USA.

Kocaffe D, Huang X \& Kocaefe Y. 2015. Dimensional stabilization of wood. Curr Forestry Rep 1: 151-161. DOI 10.1007/s40725-015-0017-5

KuČEROVÁ V, LAgaŇa R, V BOHOVÁ E ET AL. 2016. The effect of chemical changes during heat treatment on the color and mechanical properties of fir wood. BioResources 11: 9079-9094. https://doi.org/10.15376/ biores.11.4.9079-9094

Molí́ski W, Roszyk E, JaBLoŃski A et AL. 2016. Mechanical parameters of thermally modified ash wood determined by compression in radial direction. Maderas. Ciencia y Tecnología 18: 577-586.

Pelit H, Sönmez A \& Budakçi M. 2015. Effects of thermomechanical densification and heat treatment on density and brinell hardness of scots pine (Pinus sylvestris L.) and eastern beech (Fagus orientalis L.). BioResources 10: 3097-3111. doi: 10.15376/ biores.10.2.3097-3111

Priadi T, Sholihah M \& Karlinasari L. 2019. Water absorption and dimensional stability of heat-treated fast-growing hardwoods. Journal of the Korean Wood Science and Technology 47: 567-578. doi: 10.5658/ WOOD.2019.47.5.567

Rautkari L, Laine K, Kutnar A et al. 2013. Hardness and density profile of surface densified and thermally modified scots pine in relation to degree of densification. Journal of Materials Science 48: 23702375. doi: 10.1007/s10853-012-7019-5

Rumble JR. 2020. A Handbook of Chemistry and Physics. 101st Edition. CRC Press, Boca Raton.
Shmulsky R \& Jones PD. 2019. Forest Products and Wood Science: An introduction. 7th Edition. Wiley-Blackwell, West Sussex.

SHUKL_A SR. 2019. Evaluation of dimensional stability, surface roughness, colour, flexural properties and decay resistance of thermally modified Acacia auriculiformis. Maderas- Ciencia y Tecnologia 21: 433-446 doi: http:/ / dx.doi.org/10.4067/S0718-221X2019005000401

Sjostrom E. 2013. Wood Chemistry, Fundamentals and Applications. 22nd Edition. Elsevier Academic Press, New York.

Song J, Chen C, Zhu S et al. 2018. Processing bulk natural wood into a high-performance structural material. Nature 554: 224-28. doi: //doi.org/10.1038/ nature 25476

Srinivas K \& Pandey K. 2012. Effect of heat treatment on colour changes, dimensional stability, and mechanical properties of wood. Journal of Wood Chemistry and Technology 32: 304-316. https://doi. org/10.1080/02773813.2012.674170

Susanto M \& Mashudi. 2017. Growth trend of Hibiscus macrophyllus Roxb. ex hornem between provenances in Jawa. Bioexperiment 4:20-28. https://doi.org/10.23917/bioeksperimen. v4i1.3971

Tu D, Su X, Zhang T et al. 2014. Thermo-mechanical densification of Populus tomentosa var. tomentosa with low moisture content. BioResources 9: 38463854 .

Widyorini R, Xu J, Watanabe T et al. 2005. Chemical changes in steam-pressed kenaf core binderless particleboard. Journal of Wood Sci 51:26-32. DOI $10.1007 / \mathrm{s} 10086-003-0608-9$ 